\title{
Reconstruction of the Lacustrine Delta and Lake Level Change Analyzing Subsurface Geology and Geomorphology: Changes That Occurred during the Holocene in the Oguraike Reclaimed Land Area, Southern Kyoto, Japan
}

\author{
Yuka Ito $^{1}$, Fujio Masuda ${ }^{2}$ \\ ${ }^{1}$ Graduate School of Frontier Sciences, The University of Tokyo, Chiba, Japan \\ ${ }^{2}$ Department of Environment System Science, Doshisha University, Kyoto, Japan \\ Email: yuito@csis.u-tokyo.ac.jp
}

Received May 28, 2012; revised June 18, 2012; accepted June 25, 2012

\begin{abstract}
A paleo-lacustrine delta in Kyoto, Japan was reconstructed on the basis of subsurface geological and geomorphological analysis, and paleo-lake level changes were estimated from the structure of the delta. These analyses of the study region, i.e., the Oguraike reclaimed land area provided evidence that Lake Ogura existed until about 60 years ago in southern Kyoto, Japan. The Uji river delta was provided influents to this lake until ca. 400 years ago, as is indicated by an upward-coarsening delta succession of about $2-4 \mathrm{~m}$ thickness. The lake level could also have changed in the past as a result of a change in altitude of the delta-front (foreset) and delta-plain boundary, which probably reflects the lake surface elevation. About 400 years ago, the Paleo-Uji River was separated from Ogura Lake because a levee was constructed along the river for building a castle and for constructing a waterway for transportation. As a result of this construction, the lake level that was more than $13.0 \mathrm{~m}$ in elevation was reduced by $1.5 \mathrm{~m}$. In a more ancient times, the lake level experienced two stages - one in which the elevation was more than $13.5 \mathrm{~m}$, and one in which the elevation was reduced to less than $10 \mathrm{~m}$. These changes in the lake level are represented by a flat surface with four steps and small cliff of height ca. $0.5-2 \mathrm{~m}$ (relative elevation) separating them, recognized at the southern lakeshore. The observation of strata along with the archaeological survey in the north of Ogura Lake reveals that the lake level was decreased ca. 800 - 680 years ago. The lake level was at its highest during two periods, the first from before the 8th century to the end of the 8 th century and the second from the $14^{\text {th }}$ century to 400 years ago.
\end{abstract}

Keywords: Lake Level; Lake Ogura; Delta, Lacustrine Deposit; Borehole Data

\section{Introduction}

Lacustrine deposits and deltas provide some information related to lacustrine processes, paleo-lake levels and area [1]. In particular, paleo-lake level reconstruction from lacustrine deltas is an important tool in understanding paleo-environments, paleo-climatic conditions in continental areas, as well as lake environmental change by the impact of human activity [2-5]. Until 1941, Lake Ogura served as a flood-retarding basin in the southern Yamashiro basin. This lake was reclaimed and used as paddy field and housing land from 1933 to 1941. The lake level was reported to be at $10.1 \mathrm{~m}$ elevation in ordinary surveys, with $9.4 \mathrm{~m}$ being the elevation of the lowest water level and $12.3 \mathrm{~m}$ being the elevation at the maximum water level from the 19th century to 1941 [6]. The water depth was $1.7 \mathrm{~m}$ at the deepest spot. At the end of 16th century, the Uji River channel was switched by humans and was separated from Lake Ogura; the river flowed north of the lake because of work on the embankment. The Lake Ogura was reclaimed from 1933 year to 1941 year, is used as paddy field and residential area.

Paleo-lake levels in Lake Ogura and the surrounding area have previously been estimated using ancient documents and topographic and other ancient maps [6,7]. However, because of the scarcity of adequate exposures and number of boreholes, few studies have combined the sedimentology and stratigraphy of delta and associated landforms to establish paleo-lake level and area in and the Lake Ogura region. However, it is now possible to reconstruct the paleo-depositional environment in the Lake Ogura area because sufficient borehole data have 
been obtained.

The main purpose of this research is to reconstruct lake levels and water depths for Lake Ogura until c.a. 400 years ago on the basis of a high-resolution analysis of the paleo-depositional environment using multiple borehole data and a geographic information system (GIS).

\section{Location and Geological Setting}

Lake Ogura (Oguraike reclaimed land at present) is located approximately $8 \mathrm{~km}$ from the confluence of the Katsura, Uji, and Kizu Rivers in the Yamashiro basin, southern Kyoto Prefecture, central Japan (Figure 1). The study area is in the region of Yawata City, Kyoto City, Kumiyama Town, and Uji City. The size of the Oguraike reclaimed land is about $4 \mathrm{~km}$ from east to west, and about $2.5 \mathrm{~km}$ from north to south. The land is located between the Kizu and Uji Rivers, and at present is used as paddy fields and residential areas.
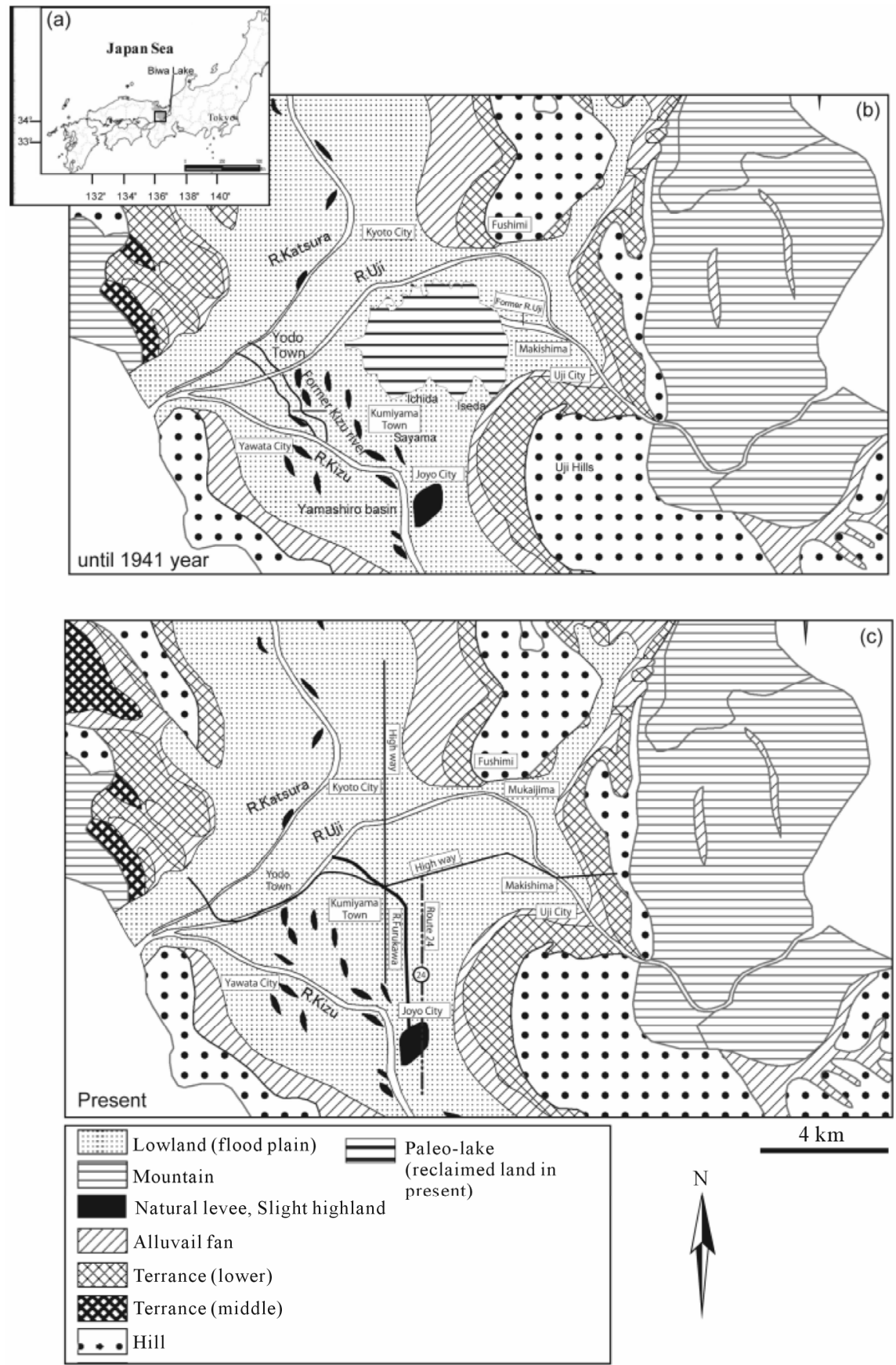

Figure 1. Location map. (a) Location of study area; (b) Morphological map of the Oguraike area until 1941 years ago; (c) Morphological map of the Oguraike reclaimed land area in present. 
Before the land was reclaimed, the perimeter of the lake was approximately $16 \mathrm{~km}$, the area was $800 \mathrm{ha}$, and the reservoir area was 4960 ha. The influx area of the waterreceiving area was 5208 ha, consisting of the lake plain, and the mountains of Eastern Kumiyama Town. The deepest spot in the bottom of the lake was the central part, and the depth got gradually shallower around the lake borders. The subsurface structure of Lake Ogura was estimated on the basis of the data reported by Kyoto Prefecture, the Ministry of Agriculture, Forestry and Fisheries of Japan and Kyoto City, and Kansai Geoinformatics Council [8]; the data comprise borehole survey data and a seismic reflection ( $\mathrm{P}$ waves) survey data. The Yamashiro basin area located at Lake Ogura has relatively thick layers of the Pleistocene to Holocene deposits with 500 - $600 \mathrm{~m}$ thick, and overlies the bedrock [9]. According to Kyoto City [10] and the Kansai Geoinformatics Council [8], Holocene deposits are about 4-m thick in the south Kyoto city area along the Katsura River; the thickness of the deposits increases rapidly from 4-m to 10 $\mathrm{m}$ in Lake Ogura, and they are $6-10 \mathrm{~m}$ thick in the northern Uji River area. Mud deposits dominate the Lake Ogura area, with silt and mud mixture deposits distributed throughout the west side of the Lake Ogura area. This lake was surrounded by the Uji Hill, Momo-yama Hills, three rivers, and floodplains.

The Katsura River from the north, the Kizu River from the south, and the Uji River from the east directly flowed into Lake Ogura until 1594. The Uji River has its headwaters in Lake Biwa and meets with the Kizu and Katsura Rivers at Oyamazaki. The Uji River is 39-km long, drains an area of $4322 \mathrm{~km}^{2}$, and has an average water discharge of $2400 \mathrm{~m}^{3} \cdot \mathrm{s}^{-1}$; and the sediment discharge downstream of the Uji River is less because sediments are deposited in Lake Biwa. This river bends at Fushimi, is about 14-km long, from Uji City to Yawata City (Figure 1(a)), and has an average riverbed slope gradient of $0.57 / 1000$. The former Uji River channel was switched to the present channel from the Makishima area to the Fushimi area by humans in 1594 in order to construct the bank (Figure 1(b)). Before the work, the river directly flowed to Lake Ogura from the Makishima area. In this paper, "the paleo-Uji River" represents the Uji River before the channel changed.

Old settlements and levees are distributed around and in the center of the Oguraike reclaimed land. These are evidences of islands that had been once been distributed in the Lake Ogura region. Ichida and Iseda settlements on the lake are particularly old and date from the 13th 16 th centuries. Additionally, systems of land subdivision in ancient Japan (Jori-system partitioning) are common around Lake Ogura, and remains dating from $300 \mathrm{BC}$ are known at Ichida and Sayama settlements.

\section{Data and Methodology}

The borehole data from the Kansai Geo-informatics Database of the Kansai Geo-informatics Council wereused in this study. This database includes ca. 50,000 borehole $\log$ data points. We can easily search and select borehole points and make cross sections of the geologic log; however, this database included only lithofacies such as gravel, sand, silt, and mud, and N-value information because this does not contain the original borehole core data, and therefore, we could not get sedimentary features and age information. However, the depositional environment could be interpreted by the use of multiple borehole data.

We created transverse and longitudinal geological cross sections on the basis of data from ca. 100 boreholes data in this area for evaluating spatially depositional system of the Lake Ogura. In this study, about 10 to 20 cross-sections of the Lake Ogura and along the shoreline were created. Six cross sections were selected as the characteristic cross sections of this area (Figure 2).

The lithofacies boundary was traced to the geologic cross sections based on combined characteristics and continuous lithology such as gravel, sand, silt, mud, lateral lithofacies change and property value ( $\mathrm{N}$-value). We used the "Shazam line" method by Gani and Bhattachrya [11] in lithofacies boundaries. The "Shzam line" is traced to aid in interpreting deltas depositional system. A Digital Elevation Model (DEM) was used to virtually represent the paleo-lake's bathymetry and water depth distribution. Five-m DEMs (Yodo, south-west Kyoto, south-east Kyoto and Uji) from the Geographical Survey Institute (GSI) were used in this study.

\section{Results and Discussion}

\subsection{Sedimentary Facies Description and Interpretation}

Three sedimentary facies were distinguished in the Lake Ogura area based on the combined characteristics of lithology and N-value. Fine grain deposits (from $4 \mathrm{~m}$ in elevation, about 10-m thick) distributed in the southern basin were correlated to the latest Pleistocene to Holocene sequence. Gravel deposits in the lowermost part belong to postglacial fluvial fan deposition based on the results of carbon dating by [12]. A mud layer 10-m thick was deposited near the Oguraike reclaimed land during a postglacial period of ca. 10,000 years; this inference is based on ${ }^{14} \mathrm{C}$ ages [13].

\subsubsection{East Shore of Lake Ogura Area}

Delta successions coarsening upward are recognized from the Uji River to the Ogura Lake area (SE-NW), on the east coast of the lake (Figure 3). The basement of 


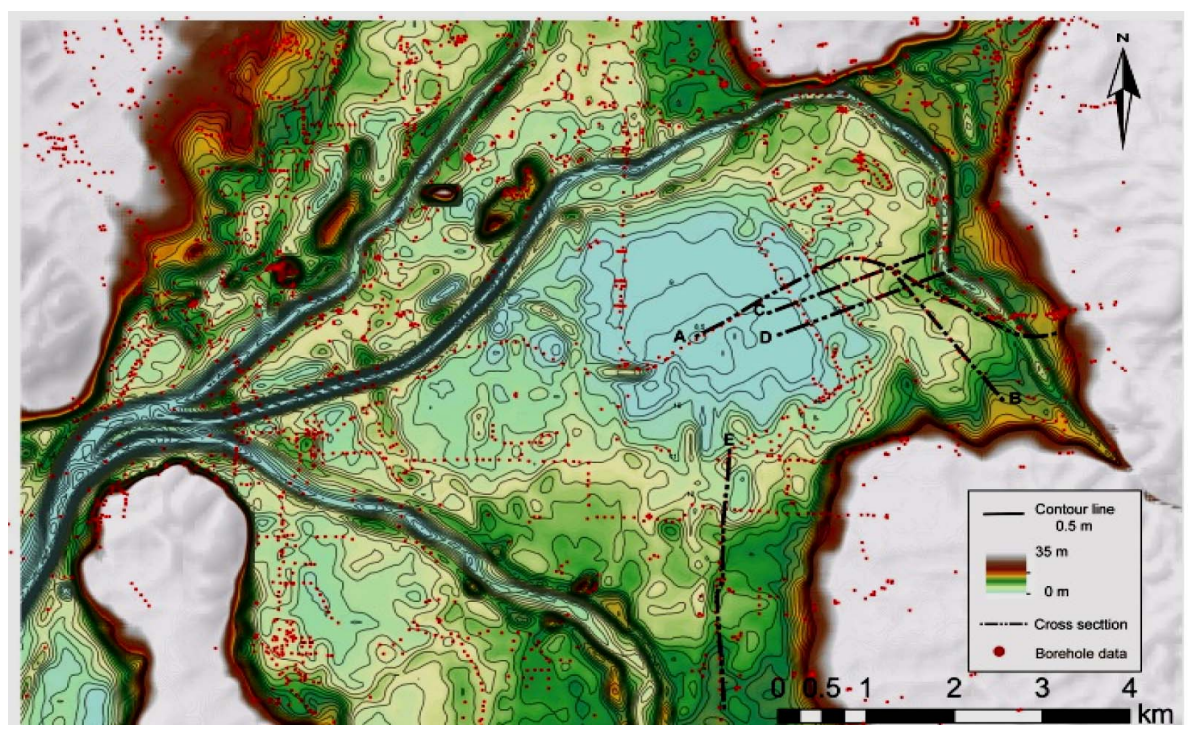

Figure 2. Location of borehole data and cross section. Dots are borehole data. A to $\mathrm{F}$ is cross section.

gravel (from $-1 \mathrm{~m}$ to $7 \mathrm{~m}$ ) occurs at the lowest part. A fine silty mud bed (from $-1 \mathrm{~m}$ to $10 \mathrm{~m}$ in elevation) is ca. 2 - $10 \mathrm{~m}$ thick in the middle parts. This mud is thinly distributed in the Makishima area, about 2 - $3 \mathrm{~m}$ thick, then rapidly thickens (to about $3-5 \mathrm{~m}$ in thickness) to the northwest of Lake Ogura, and is about $8-10 \mathrm{~m}$ in thickness in the center of the lake. This mud is interpreted as a lacustrine deposit based on elevation and $\mathrm{N}$-values, and because the bed is continuous laterally. Alternating sand and gravel beds (from 8 - $15 \mathrm{~m}$ in elevation) overly the mud bed and change from sandy gravel to sand beds in Makishima area.

The basement of gravel (from 7 - $10 \mathrm{~m}$ ) occurs from the lowermost part of the region, at the Uji River, to northwest area. A fine silty mud bed (from $9-10 \mathrm{~m}$ in elevation) is $2-4 \mathrm{~m}$ in thickness, in the middle parts. This mud is distributed from Lake Ogura to the Ohata area, and is interpreted as lacustrine deposits. The upper part of the sand-rich regions and the alternation of sand beds and gravel beds (from 11.5 - $12 \mathrm{~m}$ in elevation) are overlying the $2-3 \mathrm{~m}$-thick mud bed. The upper part of silt, found from the Ohata area to Uji hill, is about $2 \mathrm{~m}$ in thickness. The uppermost part comprises the fill.

\subsubsection{South Shore of Lake Ogura Area}

Four terraces and three small cliffs are recognized at the south of the Lake Ogura (Figure 4). The basement of gravel (from $-1 \mathrm{~m}$ to $9 \mathrm{~m}$ ) occurs in the lowermost part, and slopes from north to south. Sandy gravel beds (from $-0.5 \mathrm{~m}$ to $10 \mathrm{~m}$ in elevation) in the middle are distributed from Joyo city to the lake and along Route 24 , are about $2-7 \mathrm{~m}$ in thickness and overlie the basement of the gravel beds and are overlain by the upper parts of the mud beds. This sandy gravel indicatesupward-fining and is interpreted as a fluvial channel deposit [14]. This fluvial channel deposits is correlated to paleo-Furu River channel deposits that flowed from the postglacial period to the 8 th century. The upper parts of the mud beds (from $6.0 \mathrm{~m}-13.5 \mathrm{~m}$, and from $0-6.0 \mathrm{~m}$ ) are continuously distributed from Joyo city to Lake Ogura, are about 3 - 4 $\mathrm{m}$ in thickness and cover the middle parts of the sandy gravel beds. This mud beds are interpreted as lacustrine mud deposits because they are as thick as Lake Ogura and are widely distributed, horizontally.

The mud beds (from $6.0-9.5 \mathrm{~m}$ in elevation) that are distributed in the Oguraike reclaimed land are interpreted as the lacustrine bottom beds that were deposited until 1941. This mud bed is shown in four terraces divided gradually by three small cliffs. These lacustrine mud beds are overlain by the uppermost part of $2 \mathrm{~m}$ thick fill.

\subsection{Paleo-Lake Level Reconstruction}

\subsubsection{Lake Level Estimate by Uji Delta Deposition}

The delta succession that the Uji River formed ca. 400 years ago was recognized at the east of the lakeshore (Figure 3). The Uji River delta deposition is ca. 2 - $4 \mathrm{~m}$ in thickness with a coarsening-upwards, and is divided into topset beds of sandy and gravelly sediments, foresets of sandy sediments, and bottomsets of mud sediments. The paleo-lake level was estimated using altitude changes of boundary between the topset and foreset bed.

The topset beds of gravel are distributed $12-13 \mathrm{~m}$ in upper elevation and ca. $4 \mathrm{~m}$ in thickness in the Nakahara area, with a length of about $375 \mathrm{~m}$. The fine sandy mud and mud layer is about $3.0 \mathrm{~m}$ thick at the lower part (Figure 3). The foreset beds of alternating gravel and sand found in the Uji-toroku area at ca. $10.5-11.5 \mathrm{~m}$ in 

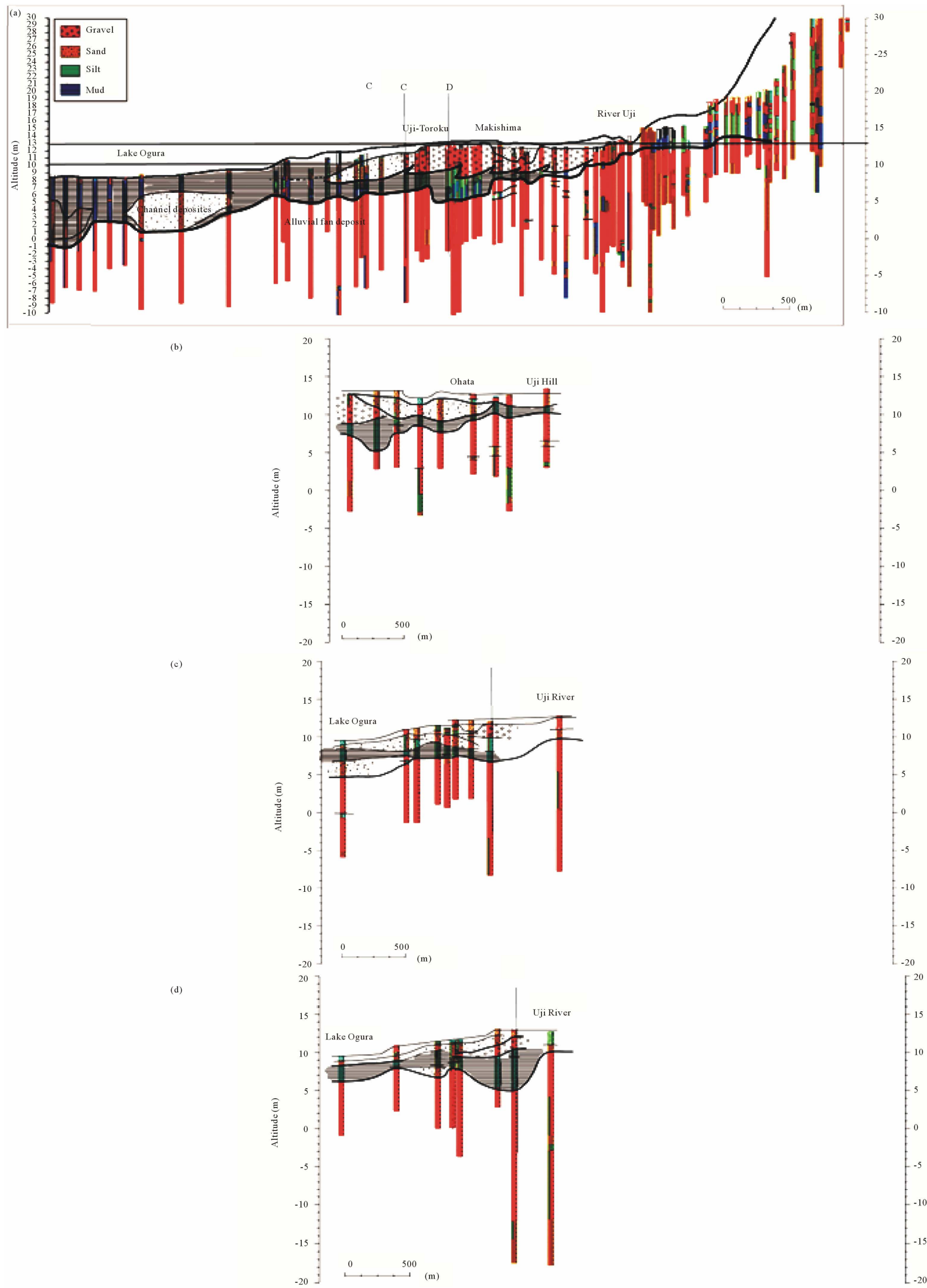

Figure 3. Cross sections in the east of the Lake Ogura. 
(a)

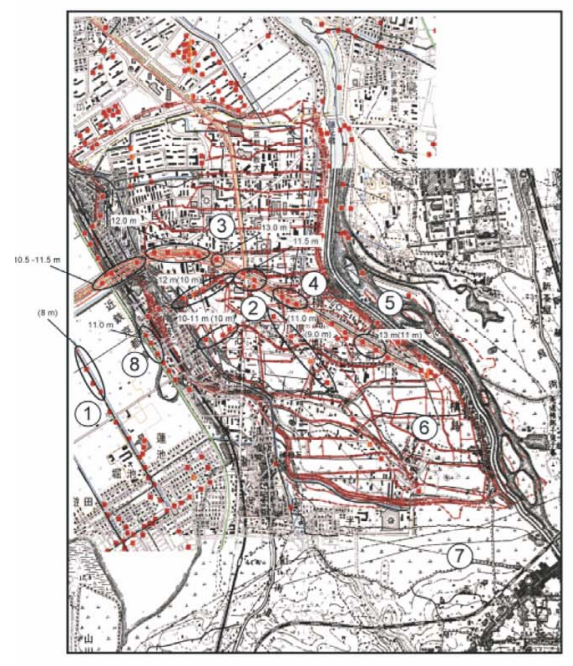

(b)

(c)
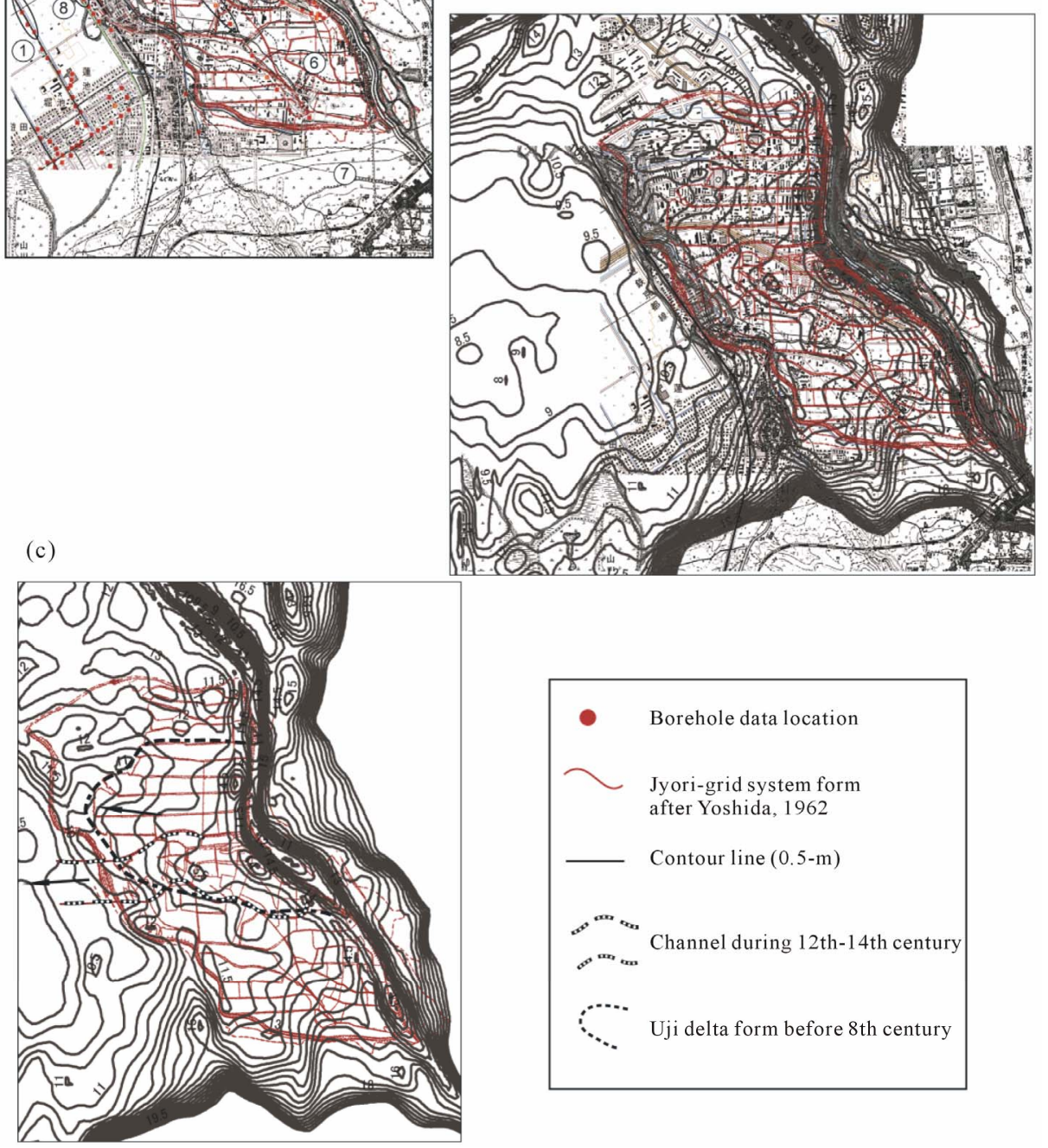

Figure 4. Delta form and old maps in the east of the Lake Ogura. (a) Jyori grid system map (Yoshida, 1962) and borehole data map. Black cycle showing topset, foreset, and bottomset of delta in cross section of Figure 3. 1: Ogura Lake; 2: Nakagawa-hara; 3: Uji-toroku; 4: Makishima; 5: Uji River; 6: Oike; 7: Uji Hill; 8: Kintetsu Railway; (b) Layering contour map generated from DEM and Jyori grid system map; (c) Dashed line (black) showing delta form. Dashed line (white and black) showing fluvial channel.

upper elevation are ca. 2 - $3 \mathrm{~m}$ thick and about $180 \mathrm{~m}$ long. The lower member consists of sandy mud of $2-5$ $\mathrm{m}$ thick. The foreset beds change to the bottomset beds of mud at 10 m elevation.

The topset beds of this delta gradually change to the foreset beds of sand in the Jyuroku area. The foreset beds are at $11.5 \mathrm{~m}$ elevation and the topset bed is $12-13 \mathrm{~m}$; thus, the paleo-lake level is estimated to between 11.5 and $13.0 \mathrm{~m}$ in elevation based on the elevation change from the topset to foreset beds.

The age of each stage are not known, however, the name relevant to the Jyori-grid system remains in this Uji delta area. Yoshida [6] reported that lakeside islands did already exist in this area in the $8^{\text {th }}$ century. Therefore, the 
paleo-lake level estimated from the Uji river delta could be corresponded to before the eight century.

In the Uji delta succession, the gravel horizon is lower by about $1 \mathrm{~m}$ than the surrounding area and indicates a feature similar to a valley in Nakahara region. The upper elevation of this gravel is about $11.5 \mathrm{~m}$. At the west of Nakahara, the gravel horizon also falls by $11.5-12 \mathrm{~m}$ in upper elevation than the surrounding area. This valley is filled by sandy gravel deposits and this surface is overlain by silt from a floodplain. The Ogura Lake is reported that lake level decreased once around the $12^{\text {th }}-14^{\text {th }}$ centuries [15]. According to Kizu Riverbed archaeological research [15], well ruins and footprint from the $12^{\text {th }}-14^{\text {th }}$ centuries were found at the riverine, which were covered with mud from the floodplain, and human trails were not preserved since $14^{\text {th }}$ century. Thus, the lake level of Lake Ogura once caused a drawdown in the $12^{\text {th }}-14^{\text {th }}$ centuries; the lake expanded and the mud was deposited [15]. Therefore, this horizon degradation indicates the possibility that the Uji River was incising the valley in the Uji delta as the lake level decreased in the $12^{\text {th }}-14^{\text {th }}$ centuries. Because the sandy gravel that filled the incised valley indicates an upward-fining, it is interpreted as a fluvial deposit.

The upper surface of sandy gravel is $10.5-11 \mathrm{~m}$ at the Kintetsu line, is as low as $8.0 \mathrm{~m}$ altitude rapidly in the west, hence, a small cliff could be formed between 8 to
$11 \mathrm{~m}$. The lake level may have dropped near Oike area in the $12^{\text {th }}-14^{\text {th }}$ centuries. However, the cause of lake level lowering is not known.

The Uji River flowed to the northwest and formed a delta to Lake Ogura until the $8^{\text {th }}$ century. The form is recognized as a lobate delta about $1.6-\mathrm{km}$ long and about 200 - $300 \mathrm{~m}$ wide on the basis of a counter map generated from 5-m DEM. After the $8^{\text {th }}$ century, this Uji River delta was developed according to the jyo-ri grid system. During the period from the $8^{\text {th }}-14^{\text {th }}$ centuries, the Uji River-channel corresponds to an area that could not be used as fields; thus, for this area the jyo-ri grid system is not confirmed in the "Jyo-ri grid system map" (Figure 4). It is also possible that the paleo-Uji River had flowed from the present Uji River to the Oike area to the northwest, and formed a small delta until about 400 years ago.

\subsubsection{Paleo-Lake Levels Reconstructed by Cliff Distribution of the Area South of the Lake Ogura Area and Lacustrine Deposition}

In southern shore area of the Lake Ogura, four flat surfaces in addition to the lake surface were recognized, and three small cliff lines could be associated with the lakeshore (Figure 5). Mud of 1 - $4 \mathrm{~m}$ thickness correlated with lacustrine bottom sediments are distributed widely

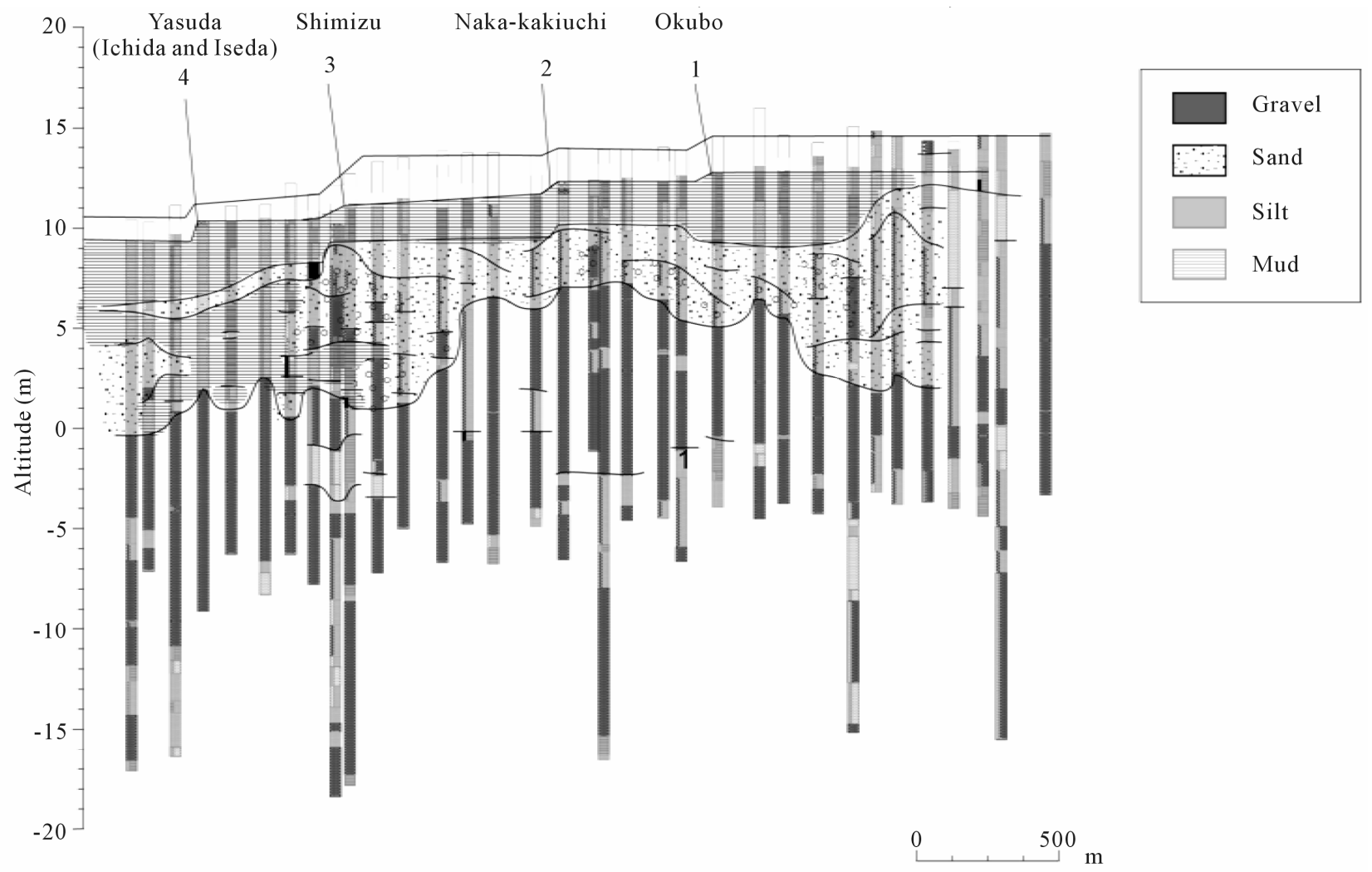

Figure 5. Cross sections in the south of the Lake Ogura. 1-4 is cliff location on Figure 6. 


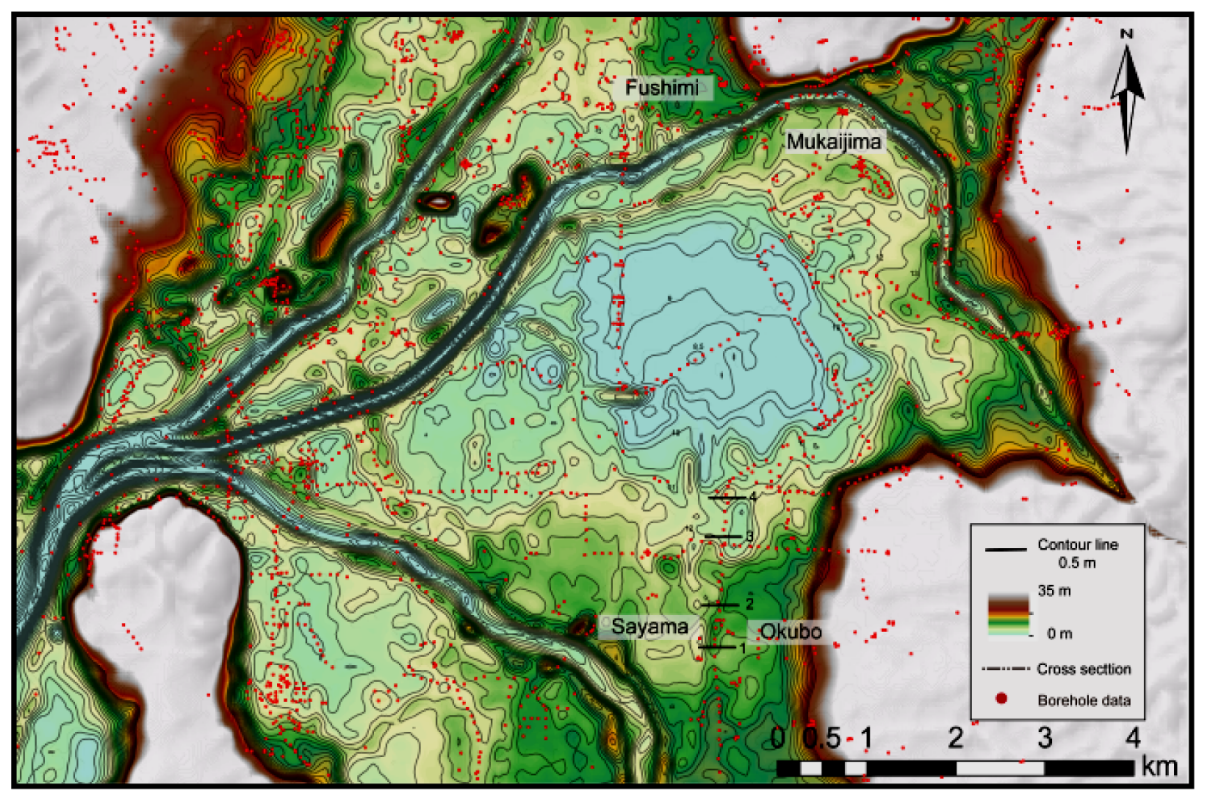

Figure 6. Map showing cliff locations (1-4).

at the bottom of these flat surfaces. The cliff line at 13.0 $13.5 \mathrm{~m}$ elevation is recognized at the Okubo area (Figures 5 and 6). It has been confirmed that from this cliff to the Naka-Kakiuchi area, the flat surface extends to 500 m. Mud of 2- $4 \mathrm{~m}$ thickness correlated with lacustrine bottom sediments are distributed at $12.5 \mathrm{~m}$ elevation. This cliff could have been correlated to the lakeshore of the $8^{\text {th }}$ century on the basis of the lake level estimated by the Uji delta. The lake level could have been between 12.2 and $13.0 \mathrm{~m}$ elevation because water level is higher than mud of 12.2 - 12.5 meters elevation, and lower than cliff line at $13.0 \mathrm{~m}$ elevation.

A cliff line is recognized at $12.5-\mathrm{m}$ elevation in the Naka-kakiuchi area (Figures $\mathbf{5}$ and $\mathbf{6}$ ). The flat surface of about $750-\mathrm{m}$ long continues from this cliff to Shimizu area. Mud of thickness $1.0-2.5 \mathrm{~m}$ correlated with the lacustrine bottom sediments are distributed at 11.8 $12.0-\mathrm{m}$ elevation below this flat. This cliff would have been a lakeshore about 400 years ago, and the lacustrine clay indicates a widespread lake area. The lake level was between 12.0 and $12.5 \mathrm{~m}$ in elevation at this time.

The cliff line is recognized at $11.8-\mathrm{m}$ elevation in Shimizu area (Figures 5 and 6). The flat surface extending $380 \mathrm{~m}$ continues from this cliff to Yasuda area. A mud layer $1-2 \mathrm{~m}$ thick correlated with the lacustrine bottom sediments are distributed at $10.5-\mathrm{m}$ elevation under this flat. This cliff could be corresponded to the lakeshore after about 400 years ago based on the distribution area of the lake according to an old map after the Taiko levee construction and the lacustrine clay indicates the range of the lake area at this time. Therefore, the lake level had been fluctuating betweenca. $10.5-11.8 \mathrm{~m}$ because the water level is higher than mud at $10.5 \mathrm{~m}$ eleva- tion, and lower than the cliff line at $11.8 \mathrm{~m}$ elevation.

The cliff line is recognized at $10.5-\mathrm{m}$ elevation in the north of Yasuda area (Figures 5 and 6). This cliff could be corresponded to the lakeshore before the reclaimedland of 1941. Because the mud at the lake bottom (ca. 3.0 $\mathrm{m}$ in thickness) is distributed at 9.5-m elevationbelow this cliff and the lake level is also reported at about 10.1-m elevation in ordinary water level [6], indicating that Lake Ogura extended to Ichida and Iseda areas.

An evidence of the lake level lowering between the $12^{\text {th }}$ and $14^{\text {th }}$ centuries might be preserved between cliff before the $8^{\text {th }}$ century and cliff before 1594 ; however, it was difficult to find the evidence of lowering of the lake level. The lake level gradually decreased, and after the construction of the Taiko levee in 1594, the level was reduced by $1.5 \mathrm{~m}$.

The lake level estimated by considering the cliff line distribution and lacustrine sediments could be corresponded to the lake level estimated by studying the Ujideltaform. The lake coverage could be maximum before the $8^{\text {th }}$ century, and the lake might be extended to the Mukaijima-Fushimi area in the northeast, and the Sayama area in the south.

Until about 400 years ago, the lake levels of the Lake Ogura fluctuated though at least three different stages. The cause is not known as yet; however, these lake level fluctuations have been associated with paleo-climatic conditions. The lowering of the lake level since 1594 may have been caused by artificial levee-construction.

This study suggests that paleo-lake level can be estimated by the considering the altitude changes in the topset and foreset of the delta and the altitude of the cliff line and lacustrine deposition. 


\section{Conclusions}

In this study, a historic lacustrine delta was successfully reconstructed on the basis of subsurface geological and geomorphological analysis using borehole data and 5-m DEM. Lake level elevations and lake area fluctuations were determined from the lacustrine delta form and lakeshore distribution.

1) Lacustrine delta deposition that the Uji River formed before the $8^{\text {th }}$ century was recognized. The delta sediment beds were ca. 2.0 - 4.0-m thick, with a coarsening-upwards, and were divided into topset beds of sandy and gravelly sediments, foresets of sandy sediments and bottomsets of mud sediments. The lake levels of Lake Ogura before the $8^{\text {th }}$ century fluctuated between elevations of $\leq 11 \mathrm{~m}$ and $13 \mathrm{~m}$; this conclusion is based on the study of the elevation changes between the topset and foreset beds.

2) The Uji delta, ca. 1.6-km long and ca. 200 - 300-m wide, was reconstructed. During the period from the $8^{\text {th }}$ to $14^{\text {th }}$ centuries the paleo-Uji river channel corresponded to an area that could not be used as fields, thus, the Jyo-ri grid system for this area was not confirmed in "Jyo-ri grid system map."

3) In the southern area of Lake Ogura, four terraces were recognized and three small cliff lines associated with the lakeshore were bounded and an ca. 1 - 4-m thick bed of mud correlated with lacustrine sediments was distributed under these flat surfaces.

Lake levels were estimated by cliff line distribution and lacustrine sediments corresponded with lake level estimated by the Uji delta succession.

\section{Acknowledgements}

We are grateful to Kansai Geo-informatics DB for providing the Kansai Geo Information database (2011).

\section{REFERENCES}

[1] J. B. Smith, "The Potential Impacts of Climate Change on the Great Lakes," Bulletin of the American Meteorological Society, Vol. 72, No. 1, 1991, pp. 21-28. doi:10.1175/1520-0477(1991)072<0021:TPIOCC >2.0.CO;2

[2] E. E. Wohl and Y. Enzel, "Data for Paleohydrology," In: N. J. Gregory, L. Starkel and V. R. Baker, Eds., Global Continental Paleohydrology, Wiley, New York, 1995, pp. 23-59.

[3] E. W. Adams, W. Schlager and F. S. Anselmetti, "Mor- phology and Curvature of Delta Slopes in Swiss Lakes: Lessons for the Interpretation of Clinoforms in Seismic Data," Sedimentology, Vol. 48, No. 3, 2001, pp. 661-679. doi:10.1046/j.1365-3091.2001.00389.x

[4] M. Machlus, Y. Enzel, S. L. Goldstein, S. Marco and M. Stein, "Reconstructing Low Levels of Lake Lisan by Correlating Fan-Delta and Lacustrine Deposits," Quaternary International, Vol. 73/74, 2000, pp. 137-144. doi:10.1016/S1040-6182(00)00070-7

[5] V. Sastre, J. Loizeau, J. Greinert, L. Naudts, P. Arpagaus, F. Anselmetti and W. Wildi, "Morphology and Recent History of the Rhone River Delta in Lake Geneva (Switzerland)," Swiss Journal of Geosciences, Vol. 103, 2010, pp. 33-42.

[6] K. Yoshida, "The Historical of Oguraike Reclaimed Land," Oguraike Land Improvement Organization, Kyoto, 1962.

[7] K. Suzuki, "History of the Oguraike Reclaimed Land and Its Surrounding Area," Journal of the Sedimentological Society of Japan, Vol. 68, No. 1, 2009, pp. 49-57.

[8] Kansaigeoinformatics Council, "New Kansai GroundKyoto Basin," Kansai Geo-Informatics Network, Osaka, 2002.

[9] K. Oike, A. Okada, K. Takemura, Y. Uemura, T. Yoshioka, K. Matsui, A. Furusawa, T. Sonoda, T. Sugimori, T. Umeda and M. Saito, "Quaternary Activity of the Ujigawa Fault Dividing the Underground Structure of the Kyoto Basin into the North and South Parts, Central Japan," Active Fault Research, Vol. 24, 2004, pp. 139-156.

[10] Kyoto City, "Report of Investigation Results of Kyoto Basin Underground Structures: The Fiscal Year of 2001," Kyoto City, 2002.

[11] R. M. Gani and P. J. Bhattacharya, "Lithostratigraphy versus Chronostratigraphy in Facies Correlations of Quarternary Deltas: Application of Bedding Correlation," SEPM Special Publication, No. 83, 2005, pp. 31-48.

[12] S. Ishida, I. Onishi, T. Nasu and T. Yokoyama, "The Holocene of Southern Part of the Kyoto Basin, Japan," Quaternary Research, Vol. 8, No. 2, 1969, p. 72.

[13] S. Ishida, "Urban Development Used Advantage of the Natural-Kyoto," In: H. Oba, K. Fujita and K. Chinzei, Eds., Nature in Japan Local 5 "Kinki”, Iwanami Shoten, Inc., Tokyo, 1995, pp. 47-48.

[14] Y. Ito, "Surface Environmental Change Reconstructed from Geomorphology and Subsurface Geology in the Lower Reaches of the Kizu River, Southern Kyoto, Central Japan: Lacustrine Deltas to the Bed-Load Dominated Rivers with Crevasse Splay,” Doshisha University, Kyoto, 2009.

[15] Y. Inochika, "Kizu River Bed Remains No. 20-21," Kyoto Archaeological Research Report, No. 145, 2011, pp. 75-104. 